\title{
Receiving Data from UAV for Geodetic Road Inventary
}

\begin{abstract}
This study presents the outline of measurement techniques using an unmanned aerial vehicle (UAV) and the elaboration of data that results from its processing. Nowadays, measurement with the use of drones is developing very quickly. There are many factors, but the biggest impact has to be the technological progress, which brings new systems, techniques, and measuring instruments every year with much-better parameters and improved accuracy. In the era of the Internet and computerization, elaboration of the measurement results from these devices becomes more transparent and easy to use; therefore, traditional paper maps are being replaced by digital maps, which are much more convenient to use when correcting errors or when applying new data.

The area where the subject of the work has been studied is located in the voivodeship of Kielce. The area that was surveyed is the National Road No. 7 on the mileage section from 561.6 to 563.3. This study was made possible thanks to Flytech Technology Co., Ltd., of Krakow for providing the necessary materials. This study aims to show one of the many aspects in which an unmanned aerial vehicle can be used. Data from the UAV method are new sources of information about the study area; therefore, an attempt to acquire data and survey the road infrastructure has contributed to completing the messages contained in this report. The idea was to present knowledge on the technical conditions and location of public roads in Poland as well as the UAV technique, its parameters, and specifications of the used measuring equipment.
\end{abstract}

Keywords: measurement, UAV, drone, cloud point, photo

* University of Agriculture in Krakow, Faculty of Environmental Engineering and Land Surveying, Krakow, Poland 


\section{Introduction}

The dynamic development of new technologies over the last decades has had a great impact on the great majority of the scientific disciplines, including geodesy and photogrammetry. Something new in the field of geodesy and photogrammetry are the use of drones for measurement on an ever-increasing scale. Despite the fact that drones for civilian use began to appear on the market only in the first decade of the $21^{\text {st }}$ century, they have already found a very wide application, and their potential seems to be unlimited [6].

At this stage of the discussion, the question will arise: What exactly is a drone? Contrary to appearances, finding a clear answer is not easy. In the literature, one can come across many terms such as unmanned aircraft (flying medium or apparatus). So, how do we determine which term is correct? While reviewing the specialist literature, it can be found that the Polish term most-frequently appearing is an unmanned aircraft designated as BSP (bezzałogowy statek powietrzny). This term is derived directly from the translation of the name unmanned aerial vehicle (UAV) into Polish, present in the English-language professional literature since the nineties of the $20^{\text {th }}$ century [1]. Both terms appear in the Polish and English versions of documents prepared by the European Organization for the Safety of Air Navigation (EUROCONTROL), which Poland joined in 2004 [7]. Taking into account the above facts, the definition of the National Defense Academy (NDA) seems to be most-appropriate for determining what a drone or unmanned aircraft is. According to the NDA, an unmanned aerial vehicle (UAV) is a "machine with a motor and without a crew on board. To stay airborne, it can use the lift generated by the action of the laws of aerodynamics on fixed wings or rotary wings (rotors) or aerostatic buoyancy (aerostat). It can be controlled by an autonomous system or remotely by the operator (from the ground, air, or a ship). Its design allows it to return and be used again. It may also be a single-use aircraft" [5].

When analyzing the English-language literature, one can find two terms: unmanned aerial vehicle system (UAVS) and unmanned aircraft system (UAS). When translated into the Polish language, it is unmanned flying system (BSL - bezzałogowe systemy latające). The name "unmanned aircraft systems" may be a bit misleading at first contact, because it can mean a defined number of unmanned aerial vehicles as well as parts of the system enabling takeoff, performance of a particular task, and landing of a UAV [1].

The legal basis for taking aerial photographs is the Regulation of the Minister of Internal Affairs and Administration of November 3, 2011, concerning databases of aerial and satellite imagery, orthophotomaps, and digital terrain models.

Nowadays, measurements with the use of drones are developing very quickly. This results from many factors, but the greatest impact has been the technological progress, which brings new systems, techniques, and measuring instruments 
every year with much-better parameters and accuracies. In the age of the Internet and computerization, working with the measurement results performed by these devices has become clearer and easier; therefore, traditional paper maps are being replaced by digital ones, which are much more comfortable to use and easier to amend or update.

The aim of this study was to present one of the many aspects in which an unmanned aerial vehicle can be employed. The data obtained using UAVs is a new source of information on the researched area; therefore, an attempt to gather data and survey the road infrastructure contributed to the information contained in the study.

\section{Research Method}

The materials used in the study were photographs taken from a UAV provided by the FlyTech UAV company in Krakow. The photos were taken in the year 2015 in the village of Tokarnia, located in Świętokrzyskie Voivodeship, District of Kielce, Municipality of Chęciny. The researched area covered a part of National Road No. 7 located in Świętokrzyskie Voivodeship. The surveyed area covered the kilometers between 561.6 and 563.3 .

\section{Measurement Equipment}

The photographs were taken using a GRYF unmanned aerial vehicle. This is a modern multipurpose device that has found its application in many fields, such as geodesy, energetics, search and rescue, or construction. Thanks to its vertical takeoff and landing capabilities, this platform may be used in small areas or in places where maneuvering space is limited. GRYF has the capabilities of both manually controlled and automatic flight, and the photographs as well as other data are transmitted in real-time during flight [3]. The GRYF UAV is made of light and durable carbon fiber. Table 1 presents the efficiency of GRYF with the use of a lens with a focal length of $21 \mathrm{~mm}$, with a forward overlap of $70 \%$ and lateral overlap of $50 \%$.

Table 1. Efficiency of GRYF UAV

\begin{tabular}{|c|c|c|}
\hline $\begin{array}{c}\text { Terrain resolution } \\
{[\mathrm{cm} / \mathrm{px}]}\end{array}$ & $\begin{array}{c}\text { Coverage area } \\
{\left[\mathrm{km}^{2}\right]}\end{array}$ & $\begin{array}{c}\text { Altitude of flight } \\
{[\mathrm{m}]}\end{array}$ \\
\hline 1 & 0.2 & 50 \\
\hline 2 & 0.4 & 100 \\
\hline 3 & 0.6 & 160 \\
\hline 5 & 0.8 & 260 \\
\hline
\end{tabular}


The Sony $\alpha$ ILCE-6000 is equipped with a Fast Hybrid AF system that benefits from the advantages of AF systems based on phase and contrast detection. This camera allows for a very sharp object observation both when recording and taking photographs (with a rate of 11 frames per second). This is possible thanks to the inbuilt BIONZ $\mathrm{X}^{\mathrm{TM}}$ image processor. It also provides for the fast operation of the AF system, which works in four dimensions thanks to the 4D FOCUS technology. This technology was developed by a combination of technical solutions, such as wide autofocus area (2D heights and widths), high autofocus speeds (3D depth), and optimized predictive tracking (4D time) [4]. This device guarantees the user a perfect image quality, as the $\alpha 6000$ body is equipped with an APS-C matrix, which is 1.6 times bigger than other $4 / 3$ sensors and 13 times bigger than the $1 / 2.3^{\prime \prime}$ matrices in a regular compact camera. The Sony $\alpha$ ILCE-6000 camera also has a 24.3-megapixel APS HD image sensor, which is equipped with microlenses aligned at different angles, thanks to which the level of light sensitivity is higher [2].

\section{Research Area Characteristics}

The area where the measurements were performed is located in Świętokrzyskie Voivodeship, District of Kielce, Commune of Chęciny, consisting of two registry units: 260403_4 (the city of Chęciny) and 260403_5 (rural area of Chęciny) (Fig. 1).

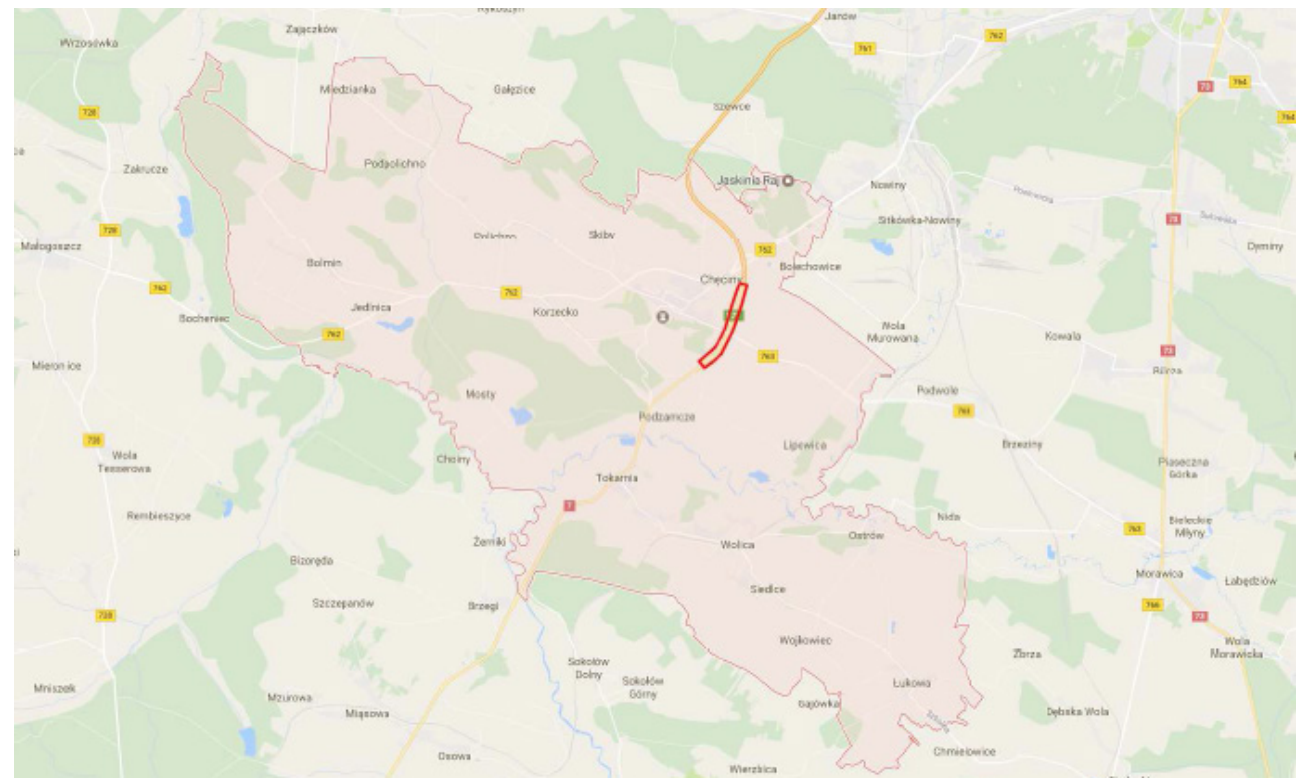

Fig. 1. Map of commune with marked area of measurement 
The object that was analyzed is the section of National Road No. 7 which runs from Żukowo near Gdansk to Chyżne (at the southern national border). The analyzed section covered kilometers from 561.6 to 563.3. The area of measurement runs across plots 348/2, 348/3 which is a part of precinct 260403_4.0001 (City of Chęciny) and plot 136/4, which is a part of the 260403_5.0014 precinct (rural area of Chęciny). The range of the measurements is depicted on an orthophotomap obtained from Google Earth (Fig. 2).

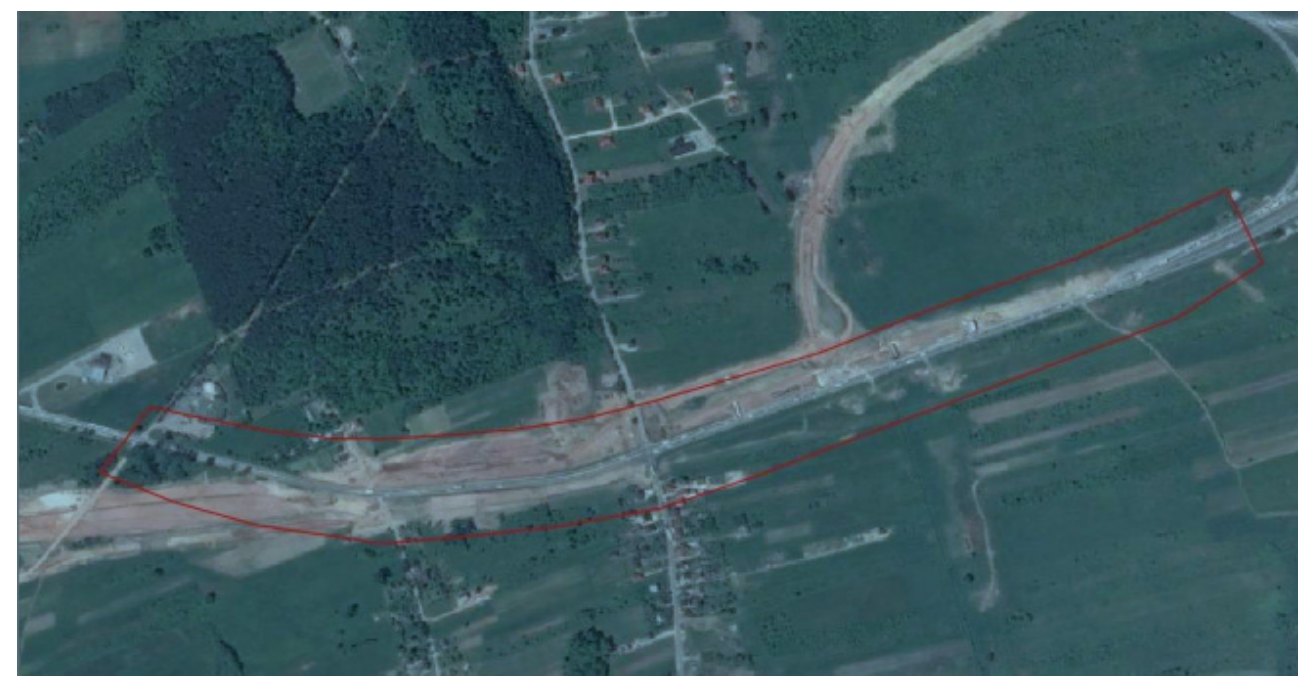

Fig. 2. Fragment of measured road

Source: M. Krzyszycha with use of Google Earth

\section{Elaboration of Measurements}

Thanks to the Flytech Company of Krakow, a set of materials from a photogrammetric flight with the use of a UAV was obtained. The gathered documentation included photographs taken using the GRYF UAV equipped with a Sony a6000 camera. Each photograph had its WGS84 three-dimensional coordinates saved in a text file. Apart from the GPS coordinates, the documentation contained other parameters such as the GPS time of each frame, altitude of the flight, or deviation from the set flight path. The materials also included text files containing a photogrammetric control network used during the measurement, which was captured in the photographs and later used in the process of elaborating the results. The first step of analyzing the documentation was selecting the photographs that captured the surveyed object. 138 photographs were selected (one of which is shown in Figure 3), which are characterized by high terrain resolution (reaching $1 \mathrm{~cm}$ per pixel). 


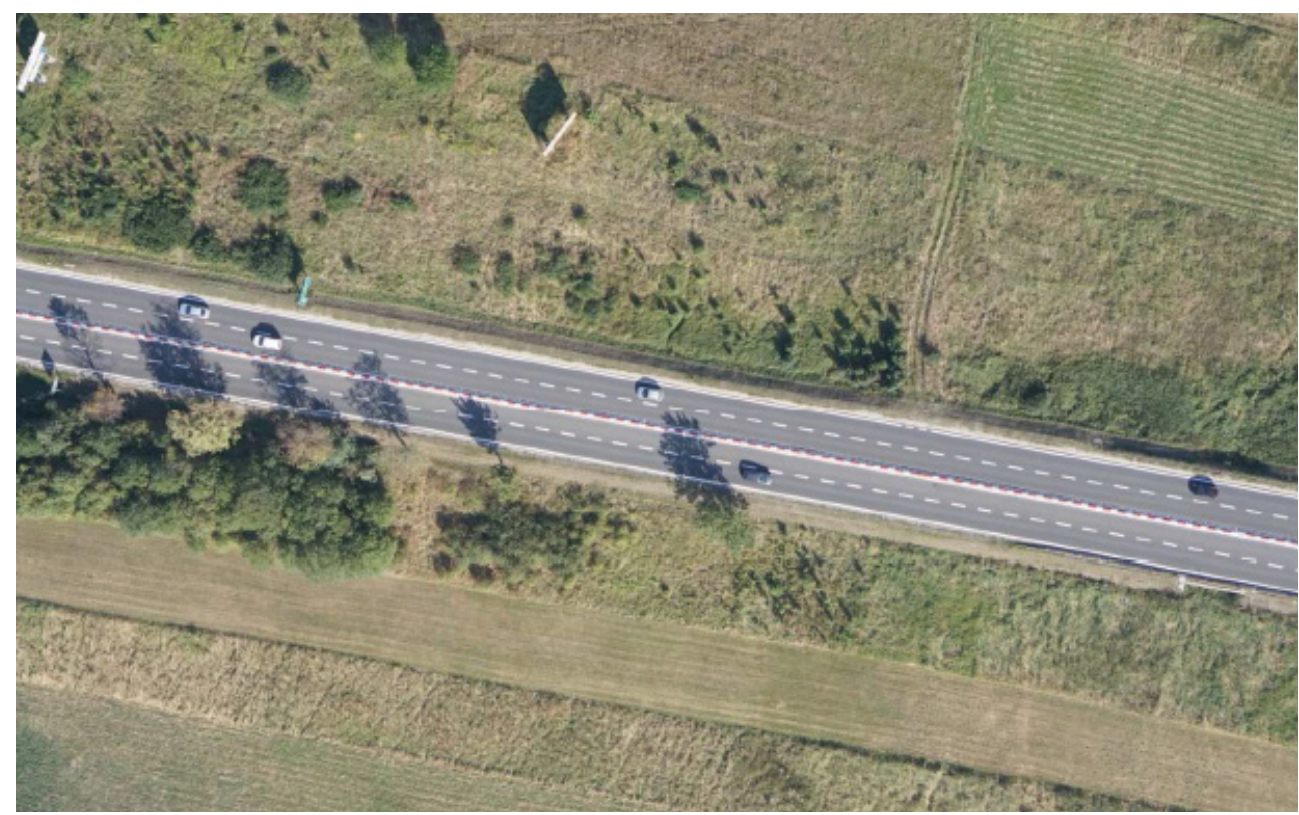

Fig. 3. Example of photograph taken during photogrammetric flight UAV

Source: materials obtained from Flytech company

Then, the photographs were loaded into an Agisoft PhotoScan along with the camera coordinates from the text file. As a result, a model was obtained that shows the numbers and positions of the photographs (Fig. 4).

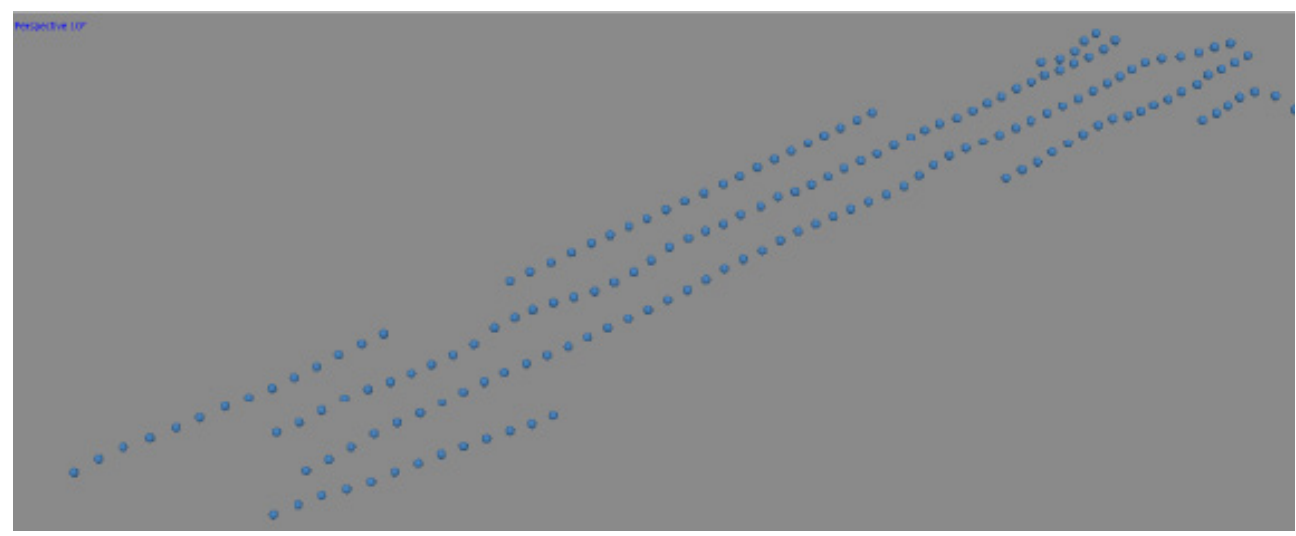

Fig. 4. Spatial model of photograph locations

The next stage was to align the photographs. In the Agisoft PhotoScan software, this is done automatically after selecting the "Align photos" option from the Work- 
flow menu. As a result, the so-called binding points of the photographs are obtained (Fig. 5), which are essential in the creation of a point cloud.

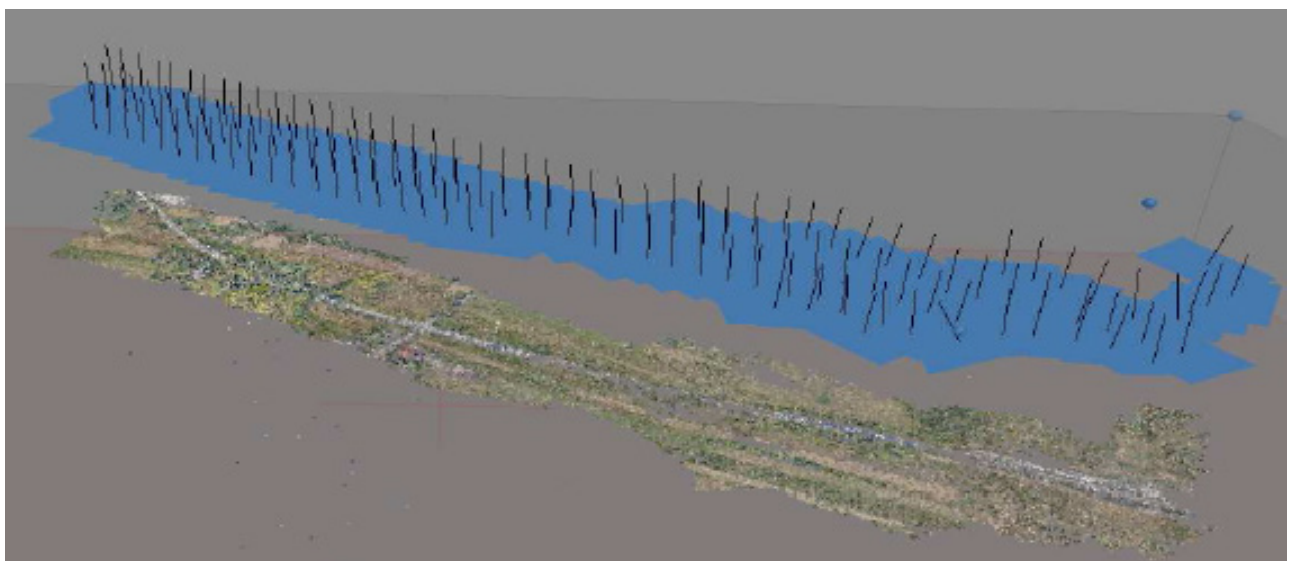

Fig. 5. Model of binding points of photographs

In order to optimize the camera position and photograph alignment for a better model-reconstruction result, the photogrammetric control network was imposed on the photographs. The points were evenly distributed along the whole area of the measurement (Fig. 6). To obtain maximum accuracy, the marker locations were verified in each of the linked photographs and then improved. In the whole area covered by the measurements, three points were found (the coordinates of which were contained in the text file provided by the Flytech company). These points were loaded into Agisoft PhotoScan software and used to optimize the position of the camera and elements of internal and external orientation. As a result, the positioning error of the photogrammetric control network was equal to $0.02 \mathrm{~m}$.

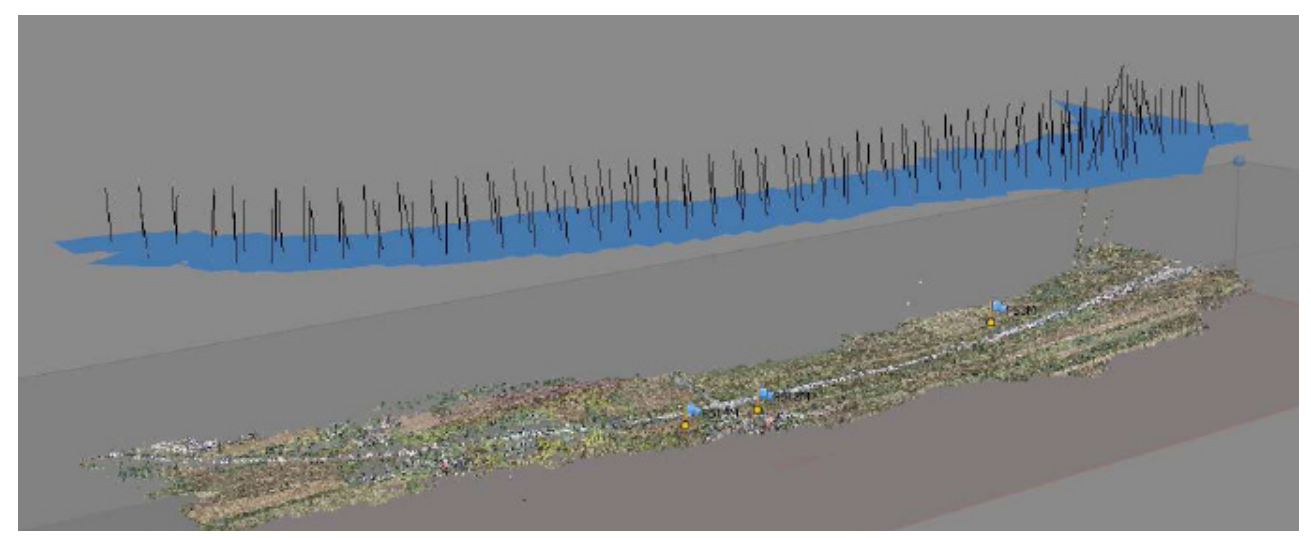

Fig. 6. Location of markers with respect to terrain 
The next step was to generate a dense point cloud based on the known positions of the camera. The program calculated the exact information on the locations of points on the photographs and generated points of the same values. With the use of the point cloud, a triangular mesh was generated (Fig. 7) along with the Digital Terrain Model (a cartographic work which represents terrain elevation).

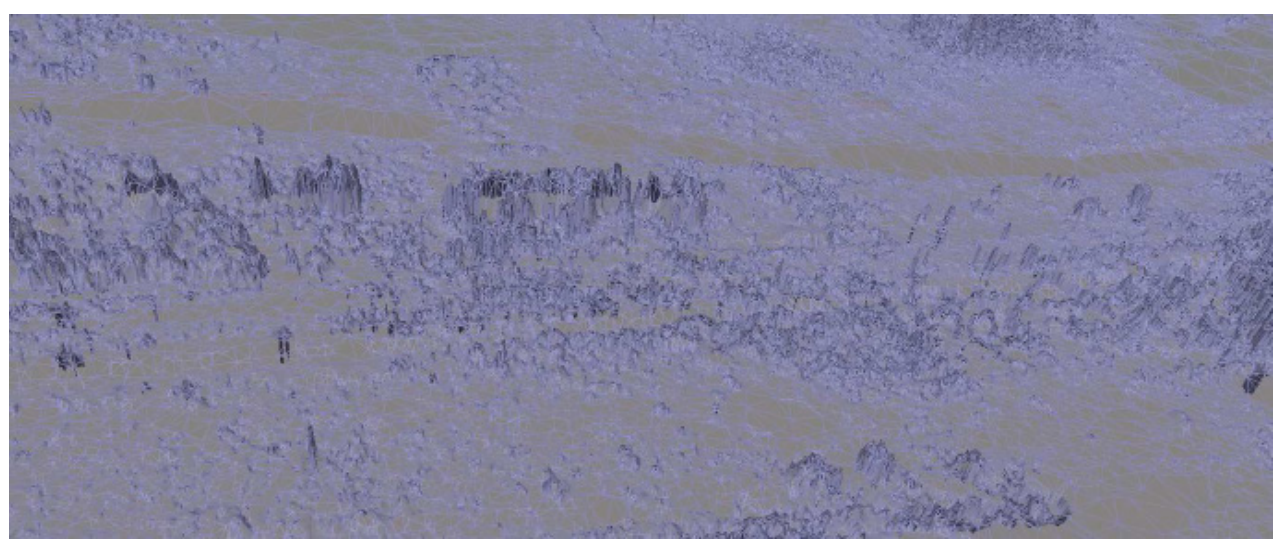

Fig. 7. Part of triangular mesh

The DTM is shown in Figure 8.

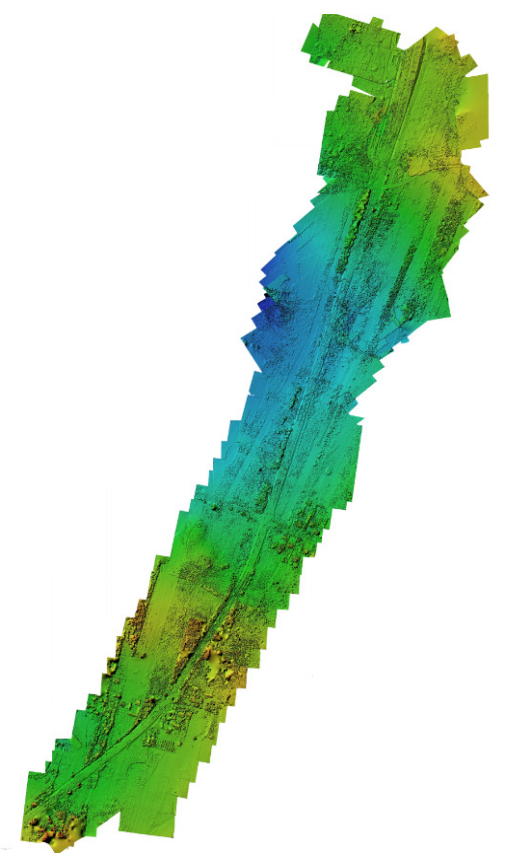

Fig. 8. DTM 
Inconsistencies in the mesh were removed in places where the number of common points was insufficient or the values differed significantly. Then, the texture was created. Using the previously obtained mesh, a 3D terrain model was generated (Fig. 9).

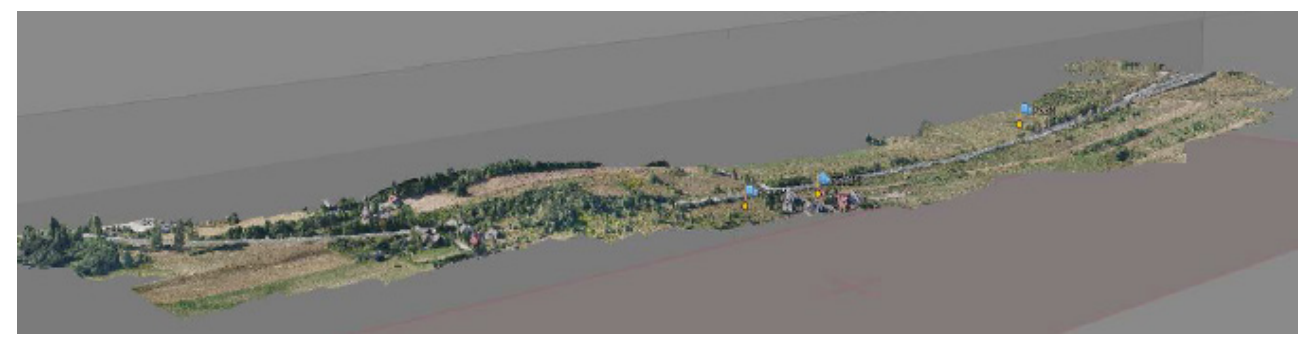

Fig. 9. 3D model

Figure 10 presents an orthophotomap of the surveyed area (this is an orthogonal projection of the terrain with a uniform scale in the selected system of coordinates and map projection).

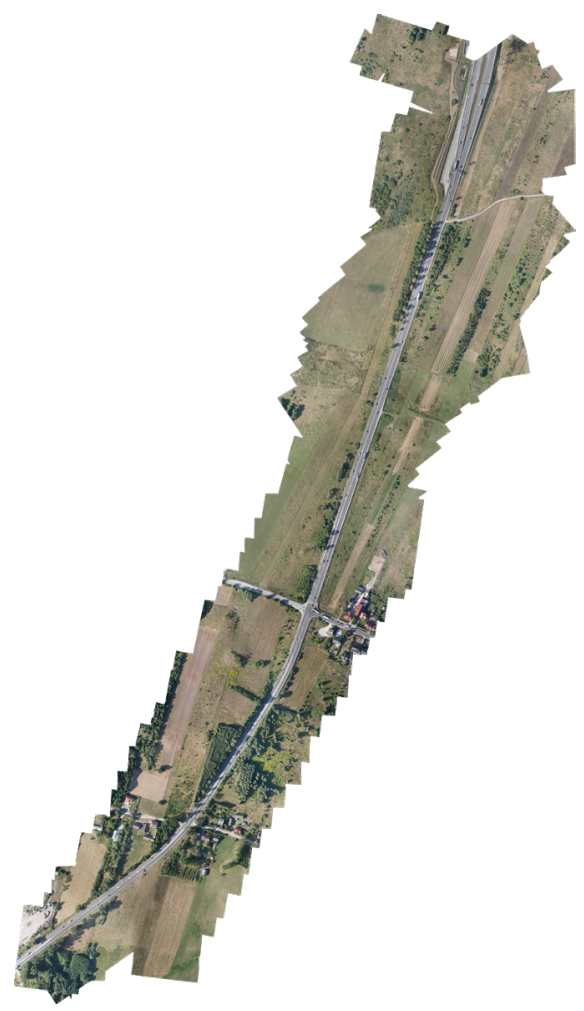

Fig. 10. Orthophotomap of surveyed area 
These processes were fully automated in the Agisoft PhotoScan program; however, they took several hours to complete due to the large amount of information contained in the photographs.

Next, the dense point cloud was exported to a file with $a^{*}$.pod extension (which is compatible with MicroStation V8i software). The point cloud was loaded into the program and used to create a cross-section of the road. Generation of the profiles also employed the Digital Terrain Model data. Due to the width of the road, the profiles were generated in a scale of 1:100, $500 \mathrm{~m}$ apart at kilometer points 562.0, 562.5, and 563.0 and at the beginning and end of the surveyed area. The generated profiles are shown in Figure 11.

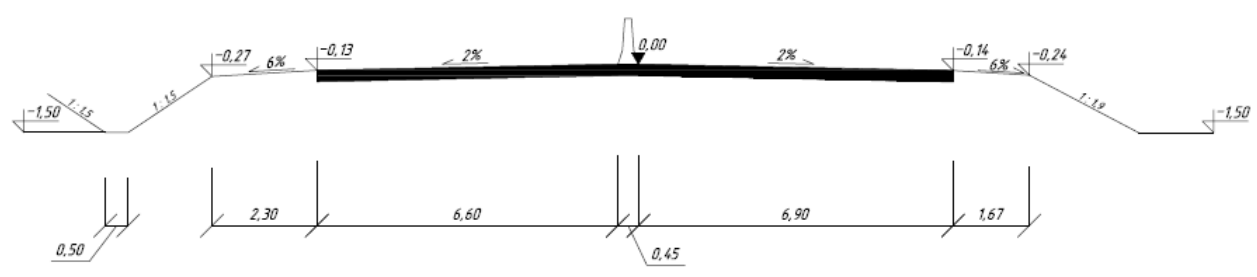

Fig. 11. Generated profiles are shown

Based on the profiles, an analysis was performed that found that the lane width at these points does not match the minimum requirements imposed by the notice [8]. The dimension of the lanes is less than seven meters, which is insufficient for a road consisting of at least two lanes in one direction. Further analysis has shown that the cross slope of the road surface is constantly equal to $2 \%$ along the whole surveyed area, which meets the technical regulations regarding roads. Next, the shoulder of the road was analyzed. Its width varied from $1.21 \mathrm{~m}$ to $2.30 \mathrm{~m}$, with an average of $1.68 \mathrm{~m}$ (which is $18 \mathrm{~cm}$ more than the minimum width stated in the notice) [8]. The longitudinal slope of the road was equal to $6 \%$, which also meets the technical standards. The last analyzed element of the cross sections was the inclination of the terrain slopes. Its value corresponded to the data in the notice [8] and was equal to 1:1.5. The only irregular inclination was found at the $562^{\text {nd }}$ kilometer and was equal to $1: 1.9$.

\section{Summary and Conclusions}

This study presented an exemplary application of an unmanned aerial vehicle in land surveying. The study involved the elaboration of materials obtained 
with use of this device. Nowadays, the data obtained using UAVs reduces the need for aerial photogrammetry data gathered using airplanes. A UAV has therefore become a major competitor for aerial photogrammetric elaboration. The photographs provided by the Flytech company were used to perform a survey of National Road No. 7. The result processing in the Agisoft PhotoScan software was a simple (although time-consuming) process. The obtained point cloud very faithfully represented the area covered by the measurements, which contributed to the accurate generation of cross section profiles with $1 \mathrm{~cm}$ precision. The orthophotomap was generated with the value of terrain pixel equal to $2.58 \mathrm{~cm}$, and the digital terrain model was generated with a resolution of $6.3 \mathrm{~cm}$ per pixel. The orthophotomap also contained technical aspects of the photography as well as the standards the road should meet during construction or modernization.

The aim of the study was to perform particular actions to eventually obtain cross sections of the road. This was done in order to compare their parameters with the minimum and maximum values given by the notice [8]. It was found that the road meets the technical standards with minor exceptions. The insufficient lane width may a result of the limited surface designated for road construction.

\section{References}

[1] Becmer D.: Bezzałogowe systemy latajace klasy I - II w przyszłym systemie walki. Zeszyty Naukowe - Wyższa Szkoła Oficerska Wojsk Lądowych im. gen. T. Kościuszki, nr 1(143), 2007, pp. 34-44.

[2] Cyfrowe.pl - sklep internetowy, www.cyfrowe.pl.

[3] FlyTech UAV sp. z o.o., [on-line:] http://www.flytechuav.com/offer/uavsystems/gryf/ [access: 07.12.2016].

[4] Haag J., 2015: The Sony A6000 and its continuous autofocus. [on-line:] https:// joerghaag.com/2015/07/23/the-sony-a6000-and-its-continuous-autofocus/ [access: 08.02.2017].

[5] Karpowicz J., Kozłowicz K.: Bezzałogowe statki powietrzne i miniaturowe aparaty latające: możliwości i zakres użycia w działaniach zbrojnych. Akademia Obrony Narodowej, Warszawa 2003.

[6] Książek S., Kasprzycki D.: Cywilne zastosowanie bezzałogowych statków powietrznych. [on-line:] www.bezpiecznelotnisko.pl/index.php/artykuly/158cywilne-zastosowanie-bezzalogowych-statkow-powietrznych [access: 05.03.2017].

[7] Maj-Mariańska J., Pietrzak P.: Prawne aspekty użytkowania bezzałogowych statków powietrznych. Bezpieczeństwo Narodowe, nr 2, 2011, pp. 197-204.

[8] Ustawa z dnia 3 lipca 2002 r. Prawo lotnicze. Dz.U. 2002, nr 130, poz. 1112 with amendments. 


\section{Pozyskiwanie danych z UAV na potrzeby geodezyjnych inwestycji drogowych}

Streszczenie: Opracowanie obejmuje pomiar bezzałogowym statkiem powietrznym (UAV - unmanned aerial vehicle) i wykorzystanie jego danych w pracach inwentaryzacyjnych. W dzisiejszych czasach pomiary z użyciem dronów rozwijają się bardzo szybko. Składa się na to wiele czynników, ale największy wpływ ma postęp technologiczny, który z każdym rokiem przynosi nowe systemy, techniki i przyrządy pomiarowe o dużo lepszych parametrach i dokładnościach. W dobie Internetu i komputeryzacji opracowywanie wyników pomiarów z tych urządzeń stało się łatwiejsze. Tradycyjne mapy na podkładach papierowych są wypierane przez mapy cyfrowe, które są o wiele wygodniejsze w obsłudze i łatwiej na nich poprawiać błędy czy nanosić nowe dane. Obszar, poddany badania, znajduje się w województwie kieleckim. Terenem, który został poddany inwentaryzacji jest droga krajowej nr 7, na odcinku o kilometrażu od 561,6 do 563,3. Przeprowadzenie badania było możliwe dzięki uprzejmości firmy Flytech z Krakowa, która udostępniła niezbędne materiały. Niniejsze opracowanie ma na celu ukazanie jednego z wielu możliwych zastosowań bezzałogowego statku powietrznego. Dane pochodzące z metody UAV są nowymi źródłami informacji o badanym terenie i wykorzystane do zinwentaryzowania infrastruktury drogowej. Zamysłem autorów było przybliżenie czytelnikowi wiedzy na temat warunków technicznych i usytuowania dróg publicznych w Polsce oraz

Słowa wykorzystania techniki UAV z podaniem jej parametrów.

kluczowe: pomiar, UAV, dron, chmura punktów, zdjęcie 